
\title{
CIÊNCIA'NATURA
}

\section{Chemical composition and antibacterial activity of Cymbopogon citratus and Cymbopogon flexuosus essential oils}

Luiz Everson Da Silva, Maria Vanaina Souza Gonçalves, Wanderlei do Amaral, Diomar Augusto de Quadros, Rodrigo Arantes Reis, Lucas Diovani Parabocz do Amaral, Luciano Fernandes Huergo e Bruna Garcia

Universidade Federal do Paraná, PR, Brasil

\begin{abstract}
Plant secondary metabolites have attracted considerable attention from the industry as consumers are increasing their interest for natural products over chemically synthesized reagents to be used as additives in food, cosmetics or pharmaceuticals. Some plant essential oils show significant antimicrobial properties and this could be exploited to produce new food preservatives or novel antimicrobial formulations. Here we describe the extraction, chemical analysis and antimicrobial properties of grass lemon Cymbopogon citratus and Cymbopogon flexuosus essential oils. Essential oils were extracted from dried leaves using hydrodestilation and their composition was established by gas chromatography coupled to mass spectrometry. Agar diffusion assays indicated that $\mathrm{C}$. citratus and $\mathrm{C}$. flexuosus essential oils act as antimicrobial agents against both gram negative and gram positive model organisms. These data support that lemon grass essential oils can be used as an alternative for microbiological control.
\end{abstract}

Key words: Antimicrobial. Essential oil. Natural product 


\section{Introduction}

Plant secondary metabolites constitute a range of different chemical compounds most of which are members of the phenylpropanoids and terpenoids family (OLIVEIRA et al., 2011). These molecules may act as chemical connections between the plant and the environment, playing roles in plant survival, defense and adaptation (GEROMINI et al. 2012; OOTONI et al. 2013).

The use of plant metabolites is attracting considerable market attention because consumers tend to opt for natural products due to their health benefits and low environmental impacts (Pereira et al. 2008). Plant essential oils are plant secondary metabolites that can be used in food, cosmetic, pharmaceutical and perfumery industry (GEROMINI et al. 2012; EKPENYONG END AKPAN, 2015; LEITE et al. 2016).

Plant essential oils can also be applied in the biocontrol of phytopathogens such as insects, fungi and bacteria. Hence, these molecules may be a sustainable alternative for agrochemicals (OOTONI et al. 2013; FONSECA et al. 2015).

Despite having a huge and diverse local flora, many exotic plant species have been introduced in Brazil since colonization (DUARTE, 2008), including the species Cymbopogon citratus and Cymbopogon flexuosus belonging to the Poaceae family. C. citratus originated from West India and C. flexuosus from east India. These two species are known as lemongrass and produce a chemical compound named citral which is an isomeric mixture of neral and geranial and gives these two plants a typical flavor (AKHILA, 2009; NISHIJIMA et al. 2014; COBOS, 2015).

The emergence of bacterial strains that are resistance to multiple antibiotics and chemicals is common treat to human health (SANTOS AND CUNHA, 2007). Antimicrobial compounds are defined as chemicals that have the ability to cause death or inhibition in microbial growth by diverse mechanisms (SOUZA AND RODRIGUES, 2012). One alternative for the substitution of classical antibiotics is the use plant natural products (Duarte, 2008).

Here we report the extraction, chemical composition and antimicrobial activities of essential oils produced by $C$. citratus and $C$. flexuosus that were cultivated in South Brazil. The oils produced by both plant species were able to inhibit the growth of both Gram-negative and Gram-positive model organisms.

\section{Materials and methods}

\subsection{Botanical material}

Plants were collected at the Experimental Farm of Canguiri, Federal University of Paraná, Pinhais, PR, Brazil on June, 2015. Plants were transported to the Herbarium of the Municipal Botanical Museum in Curitiba, PR, where they were herborized (LAWRENCE, 1951; IBGE, 1992), and registered in the collection. The species of the study were identified by depositing the exsicata of C. citratus in the herbarium of the Municipal Botanical Museum of Curitiba with the number MBM 389414 and the specimen of $C$. flexuosus in the herbarium Royal Botanic Gardens, Kew with the number H2014/02284.

\subsection{Extraction of essential oils}

The extraction of the essential oil was accomplished by hydrodistillation for 2.5 hours in a Clevenger type graduated apparatus using $100 \mathrm{~g}$ of fresh leaves in 1L of distilled water with 3 replicates (WASICKY, 1963). After the extraction, the samples were collected with precision pipette and conditioned in a freezer where they remained until the moment of the analysis.

\subsection{Determination of the chemical composition of essential oils}

Identification of the chemical constituents was performed by gas chromatography coupled to mass spectrometry (GC-MS). The essential oils were diluted in dichloromethane at the ratio of $1 \%$ and $1 \mu 1$ was injected into a gas chromatograph 6890 (Agilent) coupled to a mass detector $5973 \mathrm{~N}$. The injector was maintained at $250^{\circ} \mathrm{C}$. The separation of the constituents was performed using a capillary column HP-5MS (5\%-phenyl-95\%-dimethylpolysiloxane, $30 \mathrm{~m} \times 0,25 \mathrm{~mm} \times 0,25 \mu \mathrm{m})$ and helium as carrier gas $\left(1,0 \mathrm{~mL}\right.$ min-1). The oven temperature was programmed from 60 to $240{ }^{\circ} \mathrm{C}$ at a rate of $3^{\circ} \mathrm{C}$ min- 1 . The mass detector was operated in the electronic ionization mode $(70 \mathrm{eV})$, at a rate of 3.15 scans s- 1 and range of $40 \mathrm{a} 450 \mathrm{u}$. The transfer line was maintained at $260^{\circ} \mathrm{C}$, the ion source at $230^{\circ} \mathrm{C}$ and the quadrupole analyzer at $150^{\circ} \mathrm{C}$.

The identification of the chemical constituents was obtained by comparing their mass spectra with a library (WILEY, 1994; NIST, 2016), and also by their linear retention rates, calculated from the injection of a homologous series of hydrocarbons $\left(\mathrm{C}_{7}-\mathrm{C}_{26}\right)$ and compared with data from the literature (ADAMS, 2007).

For quantification, the diluted samples were injected into an Agilent 7890A chromatograph equipped with a flame ionization detector (DIC), operated at $280^{\circ} \mathrm{C}$. The same column and analytical conditions described above were employed except for the carrier gas used, which was hydrogen, at a flow rate of $1,5 \mathrm{~mL}$ min-1. The percentage composition was obtained by electronic 
integration of the DIC signal by dividing the area of each component by the total area (area \%).

\subsection{Antibacterial activity assay}

The bacterial species used in this work were Escherichia coli NCM 3722 (SOUPENE et al. 2003), and Bacillus thuringiensis israelensis HD-500 (ZEIGLER, 1990). The culture media used were prepared according to Sambrook (1989). Isolated colonies were cultured in LB medium and incubated on a rotating shaker at $30^{\circ} \mathrm{C}$ for B. thuringiensis and $37^{\circ} \mathrm{C}$ for E. coli for 24 hours. After this period a 1:5 dilution was performed in fresh LB to obtain an suspension containing approximately $2.10^{8}$ cells $/ \mathrm{mL}\left(\mathrm{D} \cdot \mathrm{O}_{600 \mathrm{~mm}}=0,3\right)$. An aliquot of $100 \mu \mathrm{L}$ of this dilution was evenly distributed on the surface of the solid medium in petri dishes to form the carpet of cells over the agar. Assays using B. thuringiensis were performed in LB-agar and the assays with $E$. coli were performed using M9-agar.

The antibacterial activity of the essential oils was determined using the agar diffusion technique. After letting dry the bacterial sample over the plate, $6 \mathrm{~mm}$ diameter wells were drilled with a sterile perforator, these wells received $60 \mu 1$ of the essential oils to be tested. Mineral oil was used as a negative control and kanamycin $200 \mu \mathrm{g} / \mathrm{mL}$ was used as a positive control. The plates were incubated at $30^{\circ} \mathrm{C}$ for B. thuringiensis and at $37^{\circ} \mathrm{C}$ for E. coli. After 24 hours the antibacterial activity was evaluated by measuring the halo of the inhibition zone of microbial growth around the wells. Analyses were performed in duplicates and results are presented as average \pm standard deviation.

\section{Results and discussion}

Dried leaves of Cymbopogon citratus and Cymbopogon flexuosus were subjected to essential oil extraction by hydrodestilation and its composition was established by gas chromatography coupled to mass spectrometry (Table 1). The essential oils from both species had very similar composition; the major component was citral, which is an isomer mixture of neral and geranial. Other components present in both species were linalol, geraniol and geranyl acetate. B-mircene was only identified in C. citratus composing up to $14 \%$ of the essential oil extracted from this species (Table 1). The composition of the oil of C. citratus is very similar to previously reported in the literature, the headline that some variations are justified by the different types of climate, soil composition, season extraction, among others (PEREIRA et al. 2008; SACCHETTI et al. 2005; ONAWUNMI et al. 1984).

Table 1 - Chemical composition (\%) of essential oil extracted from leaves of Cymbopogon citratus and Cymbopogon flexuosus.

\begin{tabular}{c|c|c|c|c}
\hline Compounds & IRa & IRb & Cymbopogon citratus & Cymbopogon flexuosus \\
\hline$\beta$-Mircene & 990 & 998 & 14.1 & ND \\
\hline Linalool & 1099 & 1095 & 0.8 & 31.4 \\
\hline Neral * & 1241 & 1235 & 29.6 & 3.9 \\
\hline Geraniol & 1254 & 1249 & 5.7 & 46.4 \\
\hline Geranial * & 1272 & 1264 & 39.7 & 3.3 \\
\hline Geranyl Acetate * & 1384 & 1381 & 1.8 & 10.9 \\
\hline Others & & 5.9 & 96.6 \\
\hline
\end{tabular}

(*): monoterpenes that make up the Citral. IRa: Calculated retention index. IRb: retention index of the literature. ND - Not detected.

The antibacterial effects of these essential oils we tested against two unrelated bacterial species: E. coli, used as gram negative model organism and B. thuringiensis, was used as a gram positive model organism. Bacterial cells were replicated in LB medium overnight and cultured in solid medium for $24 \mathrm{hr}$; antimicrobial activity was determined by the Agar diffusion method. The inhibitory effect was assessed by measuring the inhibition zone surrounding the wells containing the essential oil. Kanamycin at $200 \mu \mathrm{g} \cdot \mathrm{ml}^{-1}$ was used as a positive control, this concentration of kanamycin is $10 \mathrm{x}$ above the concentration normally employed to inhibit the growth of E. coli. Hence, oils capable of generating inhibition zones larger than the positive control may be considered good candidates to be employed as antimicrobial agents.

Oils from both species, C. citratus and C. flexuosus, were effective against E. coli and B. thuringiensis. The results reported in Table 2 indicate that the inhibition of growth from these oils were higher than that of the positive control kanamycin, the only exception being the C. citratus oil against E. coli (Table 2). 
The Gram-positive bacterium B. thuringiensis showed greater sensitivity than E. coli not only to the action of the oils but also to the action of the control antibiotic kanamycin (Table 2), this may be explained by the differences in the cell structures and/or metabolism between these two bacteria. Alternatively, these differences may be just related to the differences in doubling times between $E$. coli and $B$. thuringiensis as the size of the growth inhibition zones will also dependent on this variant. Antibacterial activity has already been described for $C$. citratus essential oil and in as observed here, increased efficiency was observed against gram positive bacteria (PEREIRA et al. 2008; SACCHETTI et al. 2005; ONAWUNMI et al. 1984; NAIK et al. 2010; MACHADO et al2015; LUCENA et al. 2013).

Table 2 - Antibacterial activity of essential olis.

\begin{tabular}{c|c|c}
\hline & E. coli & B. thuringiensis \\
Essencial oil & Inhibition zone $(\mathrm{mm})$ & $20.0 \pm 0.5$ \\
\hline Cymbopogon citratus & $2.7 \pm 0.5$ & $27.0 \pm 0.5$ \\
\hline Cymbopogon flexuosus & $4.5 \pm 1.0$ & $10.0 \pm 1.0$ \\
\hline Kanamycin * & $5.0 \pm 1.0$ & - \\
\hline Mineral oil** & - & $(\mathrm{mm})$
\end{tabular}

The values represent the mean inhibition zone \pm DPM (Standard deviation of the mean) in mm from two independent replicates. ${ }^{*}$ Positive control; ${ }^{* *}$ Negative Control; - no inhibition zone detected. Dilutions of the essential oils were also evaluated using mineral oil as solvent; however, no significant inhibition of bacterial growth could be detected from $10 \%(\mathrm{v} / \mathrm{v})$ dilution.

The C. flexuosus oil showed higher activity against both gram positive and gram negative Bacteria in comparison to the oil extracted from $C$. citratus (Table 2). The reason for these differences are unknown but is tempting to speculate that the higher citral content in the oil from C. flexuosus is responsible for its high antibacterial activity. Indeed, previous analysis using fractionated $C$. citratus oil indicated that citral is the major component responsible for the antibacterial activity of the essential oil, on the other hand, purified $\beta$-mircene had no significant antibacterial activity in isolation (ONAWUNMI, 1984).

Alternatively, other minor components not chemically assigned in the GC-MS analysis could be responsible for the differences in the antibacterial activities between the $C$. flexuosus and C. citratus oils (Table 1).

Essential oils have complex composition; hence, it is difficult to assign the inhibitory effect to a certain compound. Furthermore, the mechanism of bacterial growth inhibitory is not understood but is probably related to the hydrophobic interaction between oil components with the cell membrane causing its membrane disruption (DORMAN AND DEANS, 2000; FERREIRA et al. 2014). Some authors suggested that the anti-bacterial activities of essential oils are related to the major components present in the oil (AKHILA, 2009; SACCHETTI et al. 2005; LUCENA et al. 2013).

In contrast, other studies showed that the inhibitory effect can be attributed to a synergic action between major and minor components in the essential oil mix (AKHILA, 2009). Further studies will be necessary to determine the molecular basis for the different antibacterial activities of C. flexuosus and C. citratus essential oils.

\section{Conclusion}

The essential oils from $C$. flexuosus and $C$. citratus aromatic plants had citral as major component with $\beta$-mircene being found only in C. citratus. Both oils were able to inhibit growth of gram negative and gram positive bacteria with $C$. flexuosus presenting higher antibacterial activity. The results suggest that lemon grass oils can be used as a sustainable alternative in microbiological control.

\section{References}

ADAMS RP. Identification of essential oil components by gas chromatography/mass spectroscopy. Allured Publishing Corporation: Carol Stream; 2007.

AKHILA, A. Essential Oil-Bearing Grasses: The genus Cymbopogon Medicinal and Aromatic Plants. 2009.

COBOS JYG. Fontes nitrogenadas no crescimento e produção de óleo essencial de espécies de capim-limão[dissertation]. Curitiba: Universidade Federal do Paraná/UFPR; 2015. 98p. 
DORMAN HJD, DEANS SG. Antimicrobial agents from plants: antibacterial activity of plant volatile oils. Journal of Applied Microbiology. 2000; 88 (2): 308-316.

DUARTE, MCT. Atividade Antimicrobiana de Plantas Medicinais e Aromáticas Utilizadas no Brasil. Revista MultiCiência. 2006; 7 (1). http://goo.gl/PFhP3.

EKPENYONG, CE, AKPAN EE. Use of Cymbopogon Citratus Essential Oil in Food Preservation: Recent Advances and Future Perspectives. Critical Rev. Food Sci. Nutr. 2015; 6:0.

FERREIRA SB, DANTAS IC, CATÃO RMR. Avaliação da atividade antimicrobiana do óleo essencial de sucupira (Pterodon emarginatus Vogel). Rev. Bras. P1. Med. 2014; 16 (2): 225-230.

FONSECA MCM, LEHNER MS, GONÇALVES MG, PAULA-JÚNIOR TJ, SILVA AF, BONFIM FPG, et al. Potencial de óleos essenciais de plantas medicinais no controle de fitopatógenos. Rev. Bras. Pl. Med. $2015 ; 17$ (1): $45-50$.

FUNDAÇÃO INSTITUTO BRASILEIRO DE GEOGRAFIA E ESTATÍSTICA. Manual técnico da vegetação brasileira. Manuais técnicos em Geociências. 1992; 1. 92p.

GEROMINI, KVN, RORATTO FB, FERREIRA FG, POLIDO PP, SOUZA SGH, VALLE JS, et al. Atividade antimicrobiana de óleos essenciais de plantas medicinais. Arq. Ciênc. Vet. Zool. 2012; 15 (2): 127-131.

LAWRENCE GHM. Taxonomia das Plantas Vasculares, volume I, Lisboa: Fundação Galouste Gulbenkian; 1951.

LEITE CJB, SOUSA OP, MEDEIROS JOA, CONCEIÇÃO ML, SILVA VSF, SOUZA EL. Inactivation of Escherichia coli, Listeria monocytogenes, and Salmonella Enteritidis by Cymbopogon citratus D.C. Stapf. Essential Oil in Pineapple Juice. Journal of Food Protection. 2016; 79, (2): 213-219.

LUCENA YB, LEITE ACAS, OLIVEIRA KA, JUNIOR FG, RODRIGUES OG; NETO VQ. Avaliação da atividade do óleo essencial do Capim Santo (Cymbopogon citratus dc, stapf) em bactérias cariogênicas. Rev. Biol. Farm. 2013 ; 9 (2): 114-129

MACHADO TF, PEREIRA RCA, SOUSA CT, BATISTA VCV. Atividade antimicrobiana do óleo essencial do capim limão (Cymbopogon citratus) e sua interação com os componentes dos alimentos. B.CEPPA. 2015; 33 (1): 30-38.

NAIK MI, FOMDA BA, JAYKUMAR E, BHAT JA. Antibacterial activity of lemongrass (Cymbopogon citratus) oil against some selected pathogenic bactérias. Asian Pac. J. of Tropical Medicine. 2010. 3 (7): 535-538.

NISHIJIMA CM, GANEV EG, MAZZARDO-MARTINS L, MARTINS DF, ROCHA LR, SANTOS AR, et al. Citral: A monoterpene with prophylactic and therapeutic antinociceptive effects in experimental models of acute and chronic pain. Eur. J. Pharmacol. 2014; 736:16-25.

NIST Chemistry Webbook, edited by Linstrom PJ, and Mallard WG, http://webbook.nist.gov. 2016).

OLIVEIRA MMM, BRUGNERA DF, CARDOSO MG, GUIMARÃES LGL, PICCOLI RH. Rendimento, composição química e atividade antilisterial de óleos essenciais de espécies de Cymbopogon. Rev. Bras. Pl. Med. 2011; 13 (1): 8-16.

ONAWUNMI GO, YISAK W, OGUNLANA EO. ANTIBACTERIAL constituents in the essential oil of Cymbopugon citratus (DC.) Stapf. J Ethnopharmacol. 1984; 12 (3): 274-286.

OOTONI MA, AGUIAR RW, RAMOS ACC, BRITO DR, SILVA JB, CAJAZEIRA JP. Use of Essential Oils in Agriculture. J. Biotec. Biodivers. 2013; 4 (2): 162-175.

PEREIRA AA, CARDOSO MG, ABREU LR, MORAIS AR, GUIMARÃES LGL, SALGADO APSP. Caracterização química e efeito inibitório de óleos essenciais sobre o crescimento de Staphylococcus aureus e Escherichia coli. Ciênc. Agrotec. 2008; 32, (3): 887-893. 
SACCHETTI G, MAIETTI S, MUZZOLI M, SCAGLIANTI M, MANFREDINI S, RADICE M, et al. Comparative evaluation of 11 essential oils of diferent origin as functional antioxidants, antiradicals and antimicrobials in foods. Food Chemistry. 2005; 91 (4): 621-632.

SAMBROOK J, FRITSCH EF, MANIATIS T. Molecular cloning a laboratory manual. 2rd ed. New York: Cold Spring Harbor Laboratory Press; 1989.

SANTOS I, CUNHA I. Patogênicos emergentes em alimentos. Segurança e Qualidade Alimentar. 2007 (2): 10 - 13.

SOUPENE E, VANHEESWIJK WC, PLUMBRIDGE J, STEWART V, BERTENTHAL D, LEE H, et al. Physiological studies of Escherichia coli strain MG1655: growth defects and apparent cross-regulation of gene expression. J. Bacteriol. 2003; 185 (18): 5611-26.

SOUZA AA, RODRIGUES SA. Atividade antimicrobiana do óleo essencial de Rhaphiodon echinus (nees \& mart) Shauer. Revista de Biologia e farmácia. 2012; 07 (2): 12-17.

WASICKY, R. Uma modificação do aparelho de clevenger para extração de óleos essenciais. Rev. Farm. Bioquim. Univ. 1963; $1(1): 77-81$.

WILEY Registry of Mass Spectral Data, 6th edn. Wiley Interscience, New York, 1994.

ZEIGLER DR. Bacillus Genetic Stock Center Catalog of Strains, Seventh Edition, Part 2: Bacillus thuringiensis and Bacillus cereus. The Bacillus Genetic Stock Center. Columbus; 1990.

Luiz Everson Da Silva
Universidade Federal do Paraná, PR, Brasi
Coordenador do curso de licenciatura em ciências da UFPR
Email: luiz_everson@yahoo.de
Maria Vanaina Souza Gonçalves
Universidade Federal do Paraná, PR, Brasil
Graduanda em Gestão Ambiental
Email: vanainagoncalves@gmail.com
Wanderlei do Amaral
Universidade Federal do Paraná, PR, Brasil
Email: wdoamaral@homail.com
Diomar Augusto de Quadros
Universidade Federal do Paraná, PR, Brasil
Doutor em Nutrição - departamento de agroecologia
Email: diomar@ufpr.br
Rodrigo Arantes Reis
Universidade Federal do Paraná, PR, Brasil
Doutor em Bioquímica, professor da UFPR
Email: reis@gmail.com
Lucas Diovani Parabocz do Amaral
Universidade Federal do Paraná, PR, Brasil
Email: diovaniparabocz@hotmail.com
Luciano Fernandes Huergo
Universidade Federal do Paraná, PR, Brasil
Doutor em Bioquimca - professor da UFPR
Email: luciano.huergo@gmail.com
Bruna Garcia
Email:brunaklebis@live.com

